\title{
Bangkai Perahu Situs Ujung Plancu, Jambi
}

\author{
Lucas Partanda Koestoro
}

Rusmeijani Setyorini

Charunia Arni LD

Keywords: sumatra, boat, description, ancient, maritime

\section{How to Cite:}

Koestoro, L. P., Setyorini, R., \& Arni LD, C. Bangkai Perahu Situs Ujung Plancu, Jambi. Berkala Arkeologi, 15(1), 18-32. https:/ / doi.org/10.30883/jba.v15i1.652

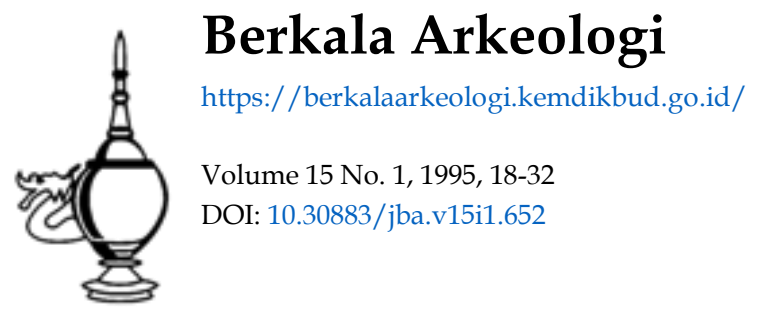

\section{(c) (1) (9)(2)}

This work is licensed under a Creative Commons Attribution-NonCommercial-ShareAlike 4.0 International License. 


\author{
Lucas Partanda Koestoro * \\ Rusmeijani Setyorini "* \\ Charunia Arni LD **
}

\title{
1. Pengantar
}

Dalam rescue excavation situs Ujung Plancu bulan Agustus 1994 lalu berhasil diangkat sisa bangkai perahu kuna. Hanya dua yang tersisa dari enam keping papan yang masih tampak di tahun 1984. Sesuai dengan tujuan kegiatan, tinggalan tersebut sekarang berada dalam bak pengkonservasian laboratorium Kantor SPSP Jambi di Jambi.

Hal yang akan disampaikan dalam tulisan ini, berkenaan dengan penempatan tinggalan tersebut dalam sejarah teknik pembangunan perahu nusantara. Berikut akan diuraikan mengenai hal tersebut.

\section{Ujung Plancu dan lingkungannya}

Secara administratif situs Ujung Plancu masuk dalam wilayah Lingkungan III Suakkandis, Desa Tanjung, Kecamatan Kumpeh, Kabupaten Batanghari, Propinsi Jambi. Secara astronomis Ujung Plancu terletak antara $01^{\circ} 23^{\prime} 18^{\prime \prime}$ LS dan $103^{\circ} 59^{\prime} 11^{\prime \prime}$ BT. Sisa bangkai perahu kuna di situs tersebut tertanam pada tebing timur Sungai Kumpeh, hanya beberapa meter di sudut timur pertemuannya dengan Sungai Batang Hari. Lahan yang ditempatinya relatif tinggi dibandingkan dengan daerah sekitar, sehingga lokasi temuan tidak tergenang air. Permukaan tanah bidang lahan ini melandai ke arah selatan dan timur, pada bagian mana orang menanami padi, karena setiap kali tergenang air.

Wilayah sekitar situs memiliki ketinggian yang bervariasi antara 2-7 $m$ dari permukaan air laut. Pada wilayah ini formasi geologinya beru-pa endapan aluvial dengan jenis tanah hidromorfik kelabu yang berteks-tur tanah gambut. Permukaan situs sendiri tanahnya berwarna coklat kekuningan dengan butiran halus.

Pada bagian timur, masih tampak sisa fondasi bata yang oleh masyarakat dikatakan sebagai bekas bangunan loji Belanda. Di sebelah

\footnotetext{
- Balai Arkeologi Yogyakarta

" Suaka Peninggalan Sejarah dan Purbakala Provinsi Jambi, Sumatera Selatan, dan Bengkulu
} 
selatan sisa bangkai perahu, pada jarak sekitar $22 \mathrm{~m}$, terdapat 20 tonggak kayu bulat dan persegi. Tonggak-tonggak kayu itu memanjang dengan orientasi baratlaut-tenggara, memagari tebing sungai. Formasi ini mengingatkan pada sisa sebuah dermaga.

Sisa keramik Cina yang bertebaran di permukaan areal situs kebanyakan berasal dari abad 11-13. Juga tepian kendi dan piring fine paste ware; tepian dan badan piring temper white ware; bagian badan fayen-ce Eropa; serta pecahan genteng.

Situs Ujung Plancu mengesankan sebagai sebuah pusat kegiatan masa lalu di salah satu persimpangan Sungai Batang Hari. Situs-situs lain seperti Suakkandes, Olak Badar, dan Gedong Karya yang tidak jauh di sekelilingnya agaknya dapat dikaitkan dengan keberadaan Situs Ujung Plancu.'

Situs Suakkandis yang berada sekitar $0,7 \mathrm{~km}$ di seberang selatan, terletak pada tebing barat.Sungai Kumpeh (gambar 1). Letak astronomisnya antara $1^{\circ} 23^{\prime} 41^{\prime \prime}$ LS dan $103^{\circ} 59^{\prime} 12^{\prime \prime}$ BT termasuk dalam wilayah Desa Tanjung, Kecamatan Kumpeh, Kabupaten Batanghari. Di tepian sungai, dekat pangkalan perahu, cukup banyak sebaran pecah-an keramik, di antaranya: pecahan pasu berbahan batuan yang glasir-nya aus, abad 13-14 (Yuan ?); bibir mangkuk bahan batuan, glasir hijau keabu-abuan, bagian dalam berhias gores bawah glasir produk Cina Selatan dari abad 12-13; bibir mangkuk seladon Long Chuan abad 1314; bibir mangkuk bahan batuan, glasir putih kehijauan dari Cina Selatan abad 12-13; atau badan mangkuk besar batuan, green ware (glasir hijau pecah seribu), dengan hias gores di bagian dalam dan luar abad 12-14 (Fukien ?); guci berbahan batuan dengan slip putih yang diperkirakan berasal dari abad 13-14 (Yuan ?); serta bibir dan badan temper white ware.

Berikutnya adalah situs Olak Badar. Sementàra orang menyebutnya situs Candi atau Sematang Pundung. Letak astronomisnya antara $01^{\circ}$

\footnotetext{
Hasil survei di penghujung tahun 1992 yang dilakukan oleh Lucas Partanda Koestoro bersama Dede Saripudin dan Widarwanto (Laboratorium Paleoekologi Radiometri Bandung) atas dukungan dana Pusat Penelitian Arkeologi Nasional. Kunjungan berikutnya serta penanganan artefak yang dijumpai dilakukan awal tahun 1994 bersama-sama dengan Pierre-Yves Manguin (dan Jeremy Manguin) serta I Made Kusumajaya dalam kaitannya dengan program bersama CNRS, LIPI, EFEO, Puslit Arkenas dan ORSTOM mengenai Settlement Ecology in the Indonesian Archipelago.
} 
23' 03" LS dan $103^{\circ} 58^{\prime} 56^{\prime \prime}$ BT, yang termasuk wilayah Desa Tanjung. Letaknya sekitar $1 \mathrm{~km}$ di seberang baratlaut Ujung Plancu, di tepian utara sungai Batang Hari. Di situs tersebut penduduk sering menjumpai bata berukuran besar, di samping sebaran keramik yang melimpah, yang umumnya berasal dari berbagai bentuk keramik Cina abad 12-14. Pecahan-pecahan keramik antara lain terdiri badan mangkuk berglasir putih keabu-abuan abad 13-14; dasar tempayan berbahan batuan dengan glasir hijau kecoklatan abad 13-14 (Yuan); badan buli berbahan batuan, glasir hijau kecoklatan, abad 13-14; badan mangkuk berglasir hijau kekuningan dengan motif gores di dalam, abad 12-13; serta ba-dan tempayan berbahan batuan yang diperkirakan berasal dari abad 13-14.

Adapun situs yang terletak di bagian hiiirnya, pada jarak sekitar 2,5 $\mathrm{km}$, adalah situs di Desa Gedong Karya. ${ }^{2}$ Letak astronomisnya antara $01^{\circ} 22^{\prime} 40^{\prime \prime} \mathrm{LS}$ dan $104^{\circ} 59^{\prime} 40^{\prime \prime} \mathrm{BT}$. Di bagian barat tengah kampung yang masuk dalam wilayah Kecamatan Kumpeh terdapat tanah tumbuh yang mengandung bata dan pecahan keramik. Ukuran bata lebar $18 \mathrm{~cm}$ dengan tebal $6 \mathrm{~cm}$.

Keramik yang terdapat di situs tersebut, antara lain bibir mangkuk besar berglasir hijau, bahan batuan, kasar, berhias padma di bagian luar dan polos di bagian dalam, berasal dari Cina Selatan abad 12-14. Bagian badan fine paste ware; bagian dasar mangkuk besar berglasir warna krem, bahan batuan dari Guan Dong di Cina Selatan, abad 13-14. Juga bibir mangkuk porselin berglasir putih keabu-abuan abad 12-13; bibir guci berbahan batuan yang glasirnya aus dengan slip warna putih di bagian luar dan dalam yang menunjukkan ciri produk abad ke 13-14 (Yuan); serta badan piring berbahan batuan, dengan glasir hijau (celadon) dari Long Chuan abad 13.

Tanah tumbuh dengan kandungan bata itu diduga sisa candi. Bila dugaan ini benar, maka temuan keramik tersebut merupakan bagian benda upacara. Time will tell mengenai dugaan ini dengan melalui penelitian yang mendalam, tentunya.

2 Dari nama lama Gedong Tebakar, yang dihubungkan dengan cerita turuntemurun akan peristiwa penyerbuan pasukan rakyat yang mampu membakar habis bangunan gudang penyimpanan komoditi dagang (lada dan sebagainya) Belanda/loji Kompeni yang berdiri di wilayah tersebut di masa lalu. Peman-faatan sumber Belanda belum menghasilkan kepastian apakah loji yang dimak-sud memang terdapat di sana atau justru loji di muara Sungai Kumpeh, yakni situs Ujung Plancu. 


\section{Hasil Penelitian Penyelamatan (rescue excavation)}

Ekskavasi penyelamatan di Situs Ujung Plancu bertujuan untuk mengangkat dan menyelamatkan sisa bangunan perahu serta pengumpulan data kepurbakalaan secara maksimal. ${ }^{3}$ Adapun temuan secara umum antara lain bagian perahu, tatal kayu, tonggak kayu, dan temuan lainnya.

\subsection{Papan perahu}

Dari sepuluh keping papan yang ditemukan, dua di antaranya terletak pada struktur aslinya. Selain itu ditemukan potongan-potongan papan lepas dalam keadaan berserakan dan tidak beraturan terletak pada bagian dasar sungai yang lebih rendah.

Dua papan yang disebutkan pertama, ditemukan pada kedalaman $179 \mathrm{~cm}$ di bawah permukaan tanah kotak ekskavasi, yakni papan-pa-pan yang masih bersatu. Ukuran masing-masing papan adalah $352 \times 29 \times 10$ $\mathrm{cm}$, serta $220 \times 29 \times 9 \mathrm{~cm}$.

Terletak di atas tumpukan tatal kayu di kedalaman sekitar $180 \mathrm{~cm}$, dua keping papan perahu itu tertanam pada tebing timur sungai Kumpeh, beberapa meter dekat pertemuannya dengan sungai Batang Hari. Kedua papan itu masih bersatu, terikat oleh pasak kayunya. Bagian papan yang tidak tertutup tanah, menjadi berlubang-lubang akibat serangan kapang, yaitu sejenis siput air pemakan kayu.

Pada permukaan kedua papan bagian badan perahu itu terdapat paku besi serta lubang untuk memasukkan paku. Di kedua tepiannya terdapat lubang untuk memasukkan pasak kayu. Paku besi dan lubang untuk memasukkan paku, berdiameter antara 0,5-0,8 cm. Sebuah paku relatif utuh masih tampak menonjol sepanjang $5 \mathrm{~cm}$. Perlu dicatat paku dan lubang-lubang paku terdapat pada jejak sisa kayu lain yang melintang di permukaan papan, yaitu di bagian gading perahu. Jarak antara jejak gading-gading satu dengan lainnya sekitar $72 \mathrm{~cm}$, dengan lebar antara $19 \mathrm{~cm}$ dan $24 \mathrm{~cm}$.

\footnotetext{
'Rescue excavation dimaksud bertujuan untuk mengangkat dan menyelamatkan sisa bangkai perahu, serta pengumpulan sebanyak mungkin data tentang kepurbakalaan di situs Ujung Plancu. Kegiatan yang dilakukan oleh tim Suaka Pe-ninggalan Sejarah dan Purbakala Propinsi Jambi, Sumatera Selatan dan Beng-kulu ini diketuai oleh Rusmeijani Setyorini. Dalam kesempatan itu Balai Arkeo-logi Palembang memperban-tukan seorang staf penelitinya.
} 
Jarak antar lubang pasak sekitar $13-15 \mathrm{~cm}$, berdiameter rata-rata 2,5 $\mathrm{cm}$. Besar diameter lubang tersebut disebabkan proses perusakan alam, seperti oleh kapang. Pasak kayunya berdiameter sekitar $2 \mathrm{~cm}$ (gambar 2). Bahan papan perahu adalah kayu jati (Tectona grandis). Sekilas dapat diketahui papan perahu itu dibentuk tidak dengan meng-gunakan gergaji melainkan dengan cara dipahat. Bahan pasak kayu, kemungkinan adalah kayu sapang (Caesalpinia sappan), sebagaimana yang diperlihatkan dengan warnanya yang coklat kemerahan. Jenis kayu ini dikenal keuletannya sehingga penggunaannya sebagai pasak dalam pembangunan perahu sangat umum dikenal.

\subsection{Tatal kayu}

Tatal kayu yang menumpuk di bawah dua papan sisa bangkai perahu berasal dari jenis kayu bulian (Eusideroxylon zwagen). Ukur-annya sekitar: $4 \times 3 \times 0,5 \mathrm{~cm} ; 7 \times 3 \times 2 \mathrm{~cm} ; 8 \times 4 \times 1 \mathrm{~cm} ; 10 \times 5 \times 2 \mathrm{~cm}$. Keletakan tatal kayu sekitar $50 \mathrm{~cm}$ lebih tinggi dibandingkan dengan keletakan temuan limbah lain yang menumpuk rata (membentuk cultu-ral bedding) sekitar $19 \mathrm{~m}$ di selatannya.

Diduga tatal kayu adalah limbah kegiatan pengerjaan pembuatan perahu. Keterangan lebih lanjut belum diketahui, mengingat selama pelaksanaan penggalian penyelamatan di Ujung Plancu ini tidak ditemukan sisa benda lain yang biasa digunakan dalam aktivitas tersebu, termasuk peralatan kerja.

\subsection{Tonggak kayu}

Seperti telah disebutkan di atas, di situs Ujung Plancu ditemukan tonggak-tonggak kayu berjumlah 20 batang. Sebagian besar berbentuk bulat dengan diameter rata-rata $30 \mathrm{~cm}$, persegi empat berukuran $23 \mathrm{~cm}$ $\times 23 \mathrm{~cm}$. Tonggak kayu bulian disusun rapi dengan orientasi baratlaut tenggara membentuk dermaga sepanjang $22 \mathrm{~m}$ yang memagari tepian timur tebing Sungai Kumpeh. Ujung baratlaut "pagar" itu berada sekitar $22 \mathrm{~m}$ sebelah selatan lokasi penemuan papan perahu kuna.

\subsection{Temuan lain}

Temuan serta dari situs Ujung Plancu baik hasil ekskavasi pada cultural bedding, maupun survei permukaan tebing sungai. Masing-masing adalah: 
a. Logam: mata uang perunggu (Cina abad 10-11 dan Hindia Belanda awal abad 19); cincin emas seberat 1,34 gram yang berdiameter lubang $1,15 \mathrm{~cm}$; paku besi dan terak besi.

b. Flora: kemiri; pinang; batok kelapa; bambu; ijuk.

c. Fauna: tulang(di antaranya babi dan ikan); karapak penyu; cangkang moluska (kerang dan siput laut dangkal serta kerang air tawar/remis)

d. Keramik: Cina abad 10-19; Vietnam abad 15-16; Persia abad 17; dan Belanda abad 19, selain itu ditemukan juga bata dan genteng.

\section{Perahu, bengkel dan dermaga}

Dalam kunjungan kerja ke situs Ujung Plancu beberapa tahun sebelumnya ditemui enam potong papan kayu. Papan-papan kayu tersebut berasal dari bagian lunas dan kerangka perahu. Papan-papan itu tampak muncul kira-kira $30 \mathrm{~cm}$ sampai $50 \mathrm{~cm}$ dari tebing sungai. Salah satu papan bagian lunas, berukuran lebar $35 \mathrm{~cm}$, tebal $8 \mathrm{~cm}$ (Bam-bang Budi Utomo dkk., 1984).

Keadaan demikian tidak dijumpai lagi ketika ekskavasi penyelamatan dilakukan. Papan kayu yang merupakan bagian dari perahu kuna hanya tinggal dua potong. Ironisnya, dalam waktu yang relatif singkat, potongan-potongan kayu berharga itu hilang begitu saja, hanya sebagian kecil yang tersisa.

Temuan yang diperoleh menunjukkan teknik penyambungan papan dalam pembuatan perahu dengan cara susun rata (carvel built). Penyatuannya memanfaatkan teknik pasak dan paku. Pasak digunakan untuk menyatukan papan satu dengan papan lainnya. Untuk menyatukan papan lambung (kulit luar) itu dengan gading-gadingnya (yang jejaknya masih ada di sana) digunakan paku besi. Dalam sejarah teknik pembuatan perahu kuna di Asia Tenggara, pemanfaatan teknik yang memadukan pasak kayu dan paku besi dijumpai-pada bangkai perahu di situs Bukit Jakas di pulau Bintan, Riau.

Perahu Bukit Jakas adalah perahu ber-"tradisi Laut Cina Selatan" bersifat campuran, berasal akhir abad XIII sampai pertengahan abad XVII. Papan-papan yang tebalnya $10 \mathrm{~cm}$ dan lebar $37 \mathrm{~cm}$ itu disambung dengan pasak kayu (berdiameter $2 \mathrm{~cm}$, panjang $20 \mathrm{~cm}$ dan jarak antar pasak $25 \mathrm{~cm}$ ) seperti dalam perahu ber-"tradisi Asia Tenggara". Sedangkan papan-papannya dipaku ke gading-gading seperti dalam "tradisi Cina". Perahu ini tentu ada hubungannya dengan perniagaan anta-ra Cina dan Asia Tenggara, dimana terjadi pengaruh Asia Tenggara atas 
perkembangan awal teknik ilmu bangunan perahu Cina Selatan (Manguin dan Nurhadi, 1987). Ukuran asal perahu sekitar $30 \mathrm{~m}$.

Pengenalan akan kronologi kekunaan di situs bangkai perahu Ujung Plancu itu, selain melalui pendekatan teknik pembangunannya yang sejajar dengan yang dijumpai di Bukit Jakas, Riau, dan perkembangan ciri-cirinya, selain itu dilakukan analisis $\mathrm{C}-14$. Analisis carbon dating atas sampel potongan kayu telah dilakukan oleh PY Manguin pada ta-hun 1986, yang memperkirakan sekitar abad XVI umur bangkai perahu tersebut, ukuran asal diperkirakan panjang sekitar $30 \mathrm{~m}$.

Perolehan lain yang dijumpai di situs tersebut, memuat informasi yang dapat digunakan untuk membentuk sebuah asumsi yang berkenaan dengan keberadaan sebuah bengkel atau tempat memperbaiki perahu. Dugaan bahwa lokasi tersebut merupakan tempat pembuatan perahu tidak didukung dengan bukti yang ada, karena hanya ditemukan 2 buah papan kayu. Selain itu tidak dijumpainya tatal kayu jati yang merupakan bahan utama pembuatan perahu. Sebagaimana diketahui, Jambi tidak mengenal adanya produk kayu jati. Kenyataan tersebut menjadikan dugaan bahwa kayu bulian merupakan limbah hasil penggantian beberapa komponen perahu.

Berawal dari asumsi lokasi tersebut sebuah bengkel, dapat diperkirakan perahu kuna tersebut "mendarat" disana untuk memperoleh perbaikan/perawatan. Selain itu kemungkinan perahu tersebut terdampar di sana dan ditinggalkan begitu saja karena tidak laik layar lagi.

Berkenaan dengan tonggak-tonggak kayu bulian yang membentuk dermaga yang dijumpai di lokasi tersebut, menunjukkan lebih muda dari bangkai perahu yang ditemukan. Sehubungan dengan sumber Belanda, dapat diketahui sisa dermaga tersebut adalah bagian atau kelengkapan dari loji kompeni yang cukup aktif melaksanakan perdagangan di sana sejak awal abad ke-17 (Wellan,1926). Sehingga tidak mengherankan bila di lokasi tersebut ditemukan potongan fayence Eropa, fragmen mangkuk Belanda, genteng, dan mata uang Hindia Be-landa awal abad ke 19.

\section{Akhir kata}

Melimpahnya keramik Cina pada situs-situs Batang Hari, khususnya produk abad ke 12-14, mengindikasikan adanya jalinan perdagangan antara Nusantara dengan Cina. Terbentuknya jaringan perdagangan itu tidak lepas dari kemampuan DAS Batang Hari dalam menyediakan 
komoditi yang luas pangsa pasarnya, dan seyogyanya diimbangi pula dengan "daya serap" pasar di sekitar Jambi akan barang-barang import. Unsur lain yang juga menentukan adalah dukungan berupa kemampu-an "suprastruktur" Malayu yang menjamin keteraturan hubungan.

Logikanya, hubungan antara hilir dan hulu Batang Hari mempengaruhi kebesaran pusat kerajaan, begitu pula sebaliknya. Bagaimanapun, apabila suprastrukturnya tidak pandai menjalin hubungan yang baik, hubungan sumbang (dilihat dari kacamata Malayu) orang huluan dengan kekuasaan lain di pantai barat Sumatera (Bengkulu) atau DAS Kampar di Riau akan muncul. Bila hal itu terjadi, sulit bagi Malayu menciptakan pasar yang baik karena banyak komoditi dagangnya yang justru dihasilkan di hulu DAS Batang Hari. Pedagang luar tidak akan memudiki Sungai Batang Hari.

Hubungan dalam konteks ini menekankan pada adanya bukan saja aspek saling menghormati, artinya ada kesejajaran power antara Malayu yang berpusat di Jambi (sekarang) dengan daerah hulu Sungai Batang Hari yang diketahui banyak memasok berbagai kebutuhan yang meramaikan perniagaan; dapat juga berkenaan dengan kondisi di mana orang huluan "menerima" Malayu di Jambi sebagai induk kekuasaannya. Dalam keadaan inilah yang dimaksudkan dengan "suprastruktur" Malayu dapat menjamin keteraturan hubungan.

Keteraturan menyangkut aspek keamanan yang memungkinkan berkembangnya perniagaan. Tanpa hal tersebut, pelayaran yang mewahanai kegiatan perdagangan jelas mengalami kebuntuan. Eratnya keterkaitan antara perdagangan dan pelayaran disebabkan keduanya berjalan sejajar sejak dulu. Sama halnya dengan ketergantungan navigasi pada ujud peradaban (berkenaan dengan teknologi).

Diketahui Sumatera terkenal dengan hasil emas dan kayu gaharu. Kayu gaharu (antara lain dari jenis Aquilaria małaccaensis) dengan aromanya yang khas diperlukan di tempat lain. Boleh jadi itu dihasilkan da-ri hutan-hutan di daerah Jambi, di DAS Batang Hari, yang merupakan bagian dari komoditi dalam perdagangan antar entreport lokal. Dan bila diingat akan cargo dari sebuah bangkai perahu di Quanzhou, Cina (Green,1983), tampak memiliki koresponden dengan bukti keberadaan jalinan hubungan dagang abad 13 antara Sumatera dan Cina. Apakah Jambi juga ada di dalamnya, bukanlah sesuatu yang mustahil. Demi-kian pula halnya dengan Vietnam. Dan apakah itu telah bermula sejak masa 
sebelumnya dan terus berlanjut pada masa sesudahnya ? Boleh jadi, dengan catatan: bukti-bukti harus diperbanyak penemuannya.

Dalam kesempatan ini, mengacu pada hasil yang diperoleh pada kegiatan di situs Ujung Plancu, tampaknya bertambah lagi sebuah ma-ta rantai untaian pengenalan akan sejarah perkembangan teknologi pembangunan perahu di kawasan nusantara. Gambaran itu adalah seperti terlampir dalam tulisan ini. Harus dilihat bahwa itu bukanlah sebuah evolusi linier yang diperoleh dari data yang lengkap, melainkan tidak lebih dari sebuah format grafik dari perbedaan perkembangan ciri yang sayangnya hanya didasari atas bukti arkeologis maupun sumber sejarah yang amat minim.

Sebagaimana diketahui, sebagai hasil 'rerja arkeologi maritim belakangan ini, bangkai perahu yang ditemukan di beberapa situs hingga beberapa waktu sebelum ini telah diklasifikasikan adanya dua teknik penyambungan elemen-elemen konstitutif perahu yaitu teknik ikat dan teknik pasak.

Teknik ikat digunakan tali ijuk (atau rotan) untuk menyatukan papanpapan badan perahu. Tali ijuk digunakan untuk menyatukan badan perahu dengan gading-gading melalui bantuan tambuku (tonjolan pada papan yang sengaja dipahat dengan bentuk persegi atau agak membulat). Pada kenyataannya, teknik yang umum dikenal di Asia Tenggara ini juga digunakan pada pembangunan perahu Viking kuna. Ini berbeda dengan teknik jahit yang juga menggunakan tali (ijuk, rotan maupun bahan lain) untuk menyatukan papan-papan badan perahu dengan cara membuat simpul tali yang terus bersambung, sebagaimana layaknya orang menjahit (Lucas,1995). Seperti yang dikerjakan di Samudera Hindia. 
Tabel evolusi teknik pembangunan perahu di Asia Tenggara dan Laut Cina Selatan

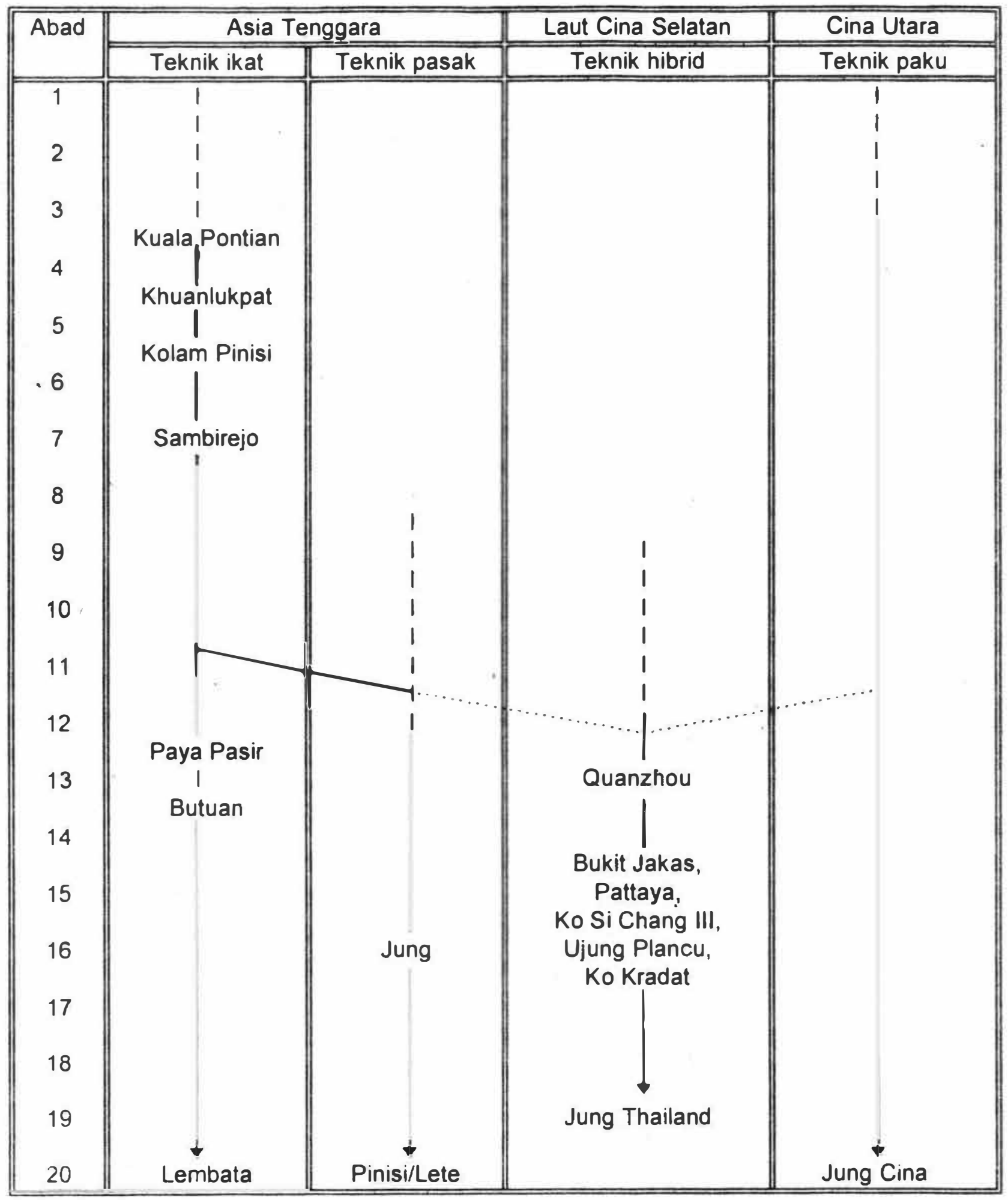


Bukti tertua pemanfaatan teknik ikat di Asia Tenggara dijumpai di situs Kuala Pontian, Malaysia, ditunjukkan pada bahan untuk kalibrasi dari abad 3-5 (Booth,1984). Sisa bangkai perahu ditemukan di situs Khuan Luk Pat di Thailand Selatan, Kolam Pinisi, Sambirejo, dan Paya Pasir di Sumatera, serta Butuan di Philipina. Perlu diketahui teknik ikat tetap digunakan hingga kini dalam pembangunan perahu penangkap ikan paus oleh sebagian masyarakat di Pulau Lembata (Lomblen), Nu-sa Tenggara Timur.

Berkenaan dengan teknik pasak, walaupun bukti arkeologis belum dijumpai, sumber Portugis abad 16 mendeskripsikan tentang jung berkapasitas 500 ton. Dalam perahu bertradisi Asia Tenggara itu tidak dikenal pemakaian simpul tali atau paku. Pemanfaatan teknik pasak te-rus berlanjut hingga beberapa waktu berselang, sebagaimana terlihat dalam pembangunan perahu pinisi di Sulawesi dan lete di Madura.

Klasifikasi kedua dibagi menjadi dua yaitu: a) perahu yang seluruhnya menggunakan pasak dan b) perahu yang cara penyambungan papan dengan gading-gadingnya menggunakan paku (Lucas,1995). Teknik terakhir ini oleh PY Manguin dinamakan teknik hibrid (Laut Cina Selatan). Bersama-sama dengan bangkai perahu dari situs Quanzhou di Cina, Pattaya, Ko Si Chang III, dan Ko Kradat di Thailand, bangkai perahu situs Ujung Plancu termasuk dalam jenis ini. Pemanfaatan tek-nik demikian tampaknya berakhir pada sekitar abad 19, sebagaimana yang ditunjukkan oleh sisa bangkai perahu (jung) di perairan Thailand.

Bagaimanapun, temuan situs Ujung Plancu telah menyodorkan talentanya bagi pengenalan beberapa aspek kehidupan masyarakatnya di masa lalu. Sisa bangkai perahu, membuktikan adanya lalu-lalang pelayaran dan perdagangan di sepanjang DAS Batang Hari pada abad ke 16. Saat pedagang Muslim menghindari Malaka yang sebelumnya merupakan salah satu pangkalan dagang mereka. Ini berkenaan pula dengan "kemunculan" Aceh sebagai pengganti peran Malaka yang telah diduduki Portugis.

Keberadaan situs bangkai perahu Ujung Plancu berkaitan dengan teknologi pembangunan perahu pada masanya. Diharapkan data yang terkumpul dapat dikonservasi dan memberikan informasi bagi semua sektor untuk berbagai keperluan. 


\section{KEPUSTAKAAN}

Bambang Budi Utomo,Jahdi Zaim,Sapri Hadi Wisastra.1984. Situs-situs arkeologi di daerah tepi sungai Batang hari. Amerta 8 Jakarta: Puslit Arkenas. hal 34-46

Booth,B.1984.A Handlist of Maritime Radiocarbon Dates, dalam IJNA, 13(3), hal. 189-204

Green,Jeremy,1983. The Song Dynasty Shipwreck at Quanzhou, Fujian Province, People's Republic of China dalam International Journal of Nautical Archaeology, 12 (3), hal. 253-261

1990. Maritime Archaeology in Southeast and East Asia, dalam Antiquity, 64(243), hal. 347-363

Hughes-Stanton,Penelope \& Rose Kerr.tt.,Kiln Sites of Ancient China. London: Oriental Ceramic Society

Lucas Partanda Koestoro,1994.Bangkai Perahu, Pengenalannya Sebagai Obyek Arkeologi. Evaluasi Hasil Penelitian Arkeologi di Palembang

1995,Penempatan Situs-Situs Bangkai Perahu Indonesia Dalam

Sejarah Teknik Pembangunan Perahu Di Asia Tenggara, dalam: Hariani Santiko dkk.(eds.), Kirana: Persembahan untuk Prof.Dr. Haryati Soebadio. Jakarta: PT Intermasa, hal. 203-216

Manguin,Pierre-Yves, 1985, Sewn-plank Craft of Southeast Asia. A Preliminary Survey, dalam: S Mc Gail \& E Kentley (ed), Sewn Planked Boats Oxford: National Maritime Museum

Manguin, Pierre-Yves dan Nurhadi, 1987.Perahu karam di situs Bukit Jakas, Propinsi Riau, Sebuah laporan sementara dalam 10 Tahun Kerjasama Pusat Penelitian Arkeologi Nasional Dan Eco1e Francaise d'Extreme-Orient. Jakarta:Puslit Arkenas, hal 43-64.

Miksic,John N.1986. Thai and Vietnamese Pottery in Indonesia and Fifteenth-Century Trade in Southeast Asia. Makalah dalam Pertemuan IImiah Arkeologi IV di Cipanas 
Nooteboom,C.1950. Sumatra en de zeevaart op de Indische Oceaan, dalam Indonesie, IV, hal. 119-127

Rusmeijani Setyorini,dkk.,1995,Laporan Pengangkatan Perahu Kuno Di Situs Ujung Plancu, Desa Tanjung, Kecamatan Kumpeh, Kabupaten Batanghari, Propinsi Jambi. Jambi:Suaka Peninggalan Sejarah dan Purbakala Propinsi Jambi, Sumsel dan Bengkulu

Scott,WH.1981.Boat-Building and Seamenship in Classic Philippine Society, Anthropological Paper No. 9. Manila: National Museum

Wellan,JWJ.1926. Onze eerste vestiging in Djambi BKI 82 hal.339-402. 


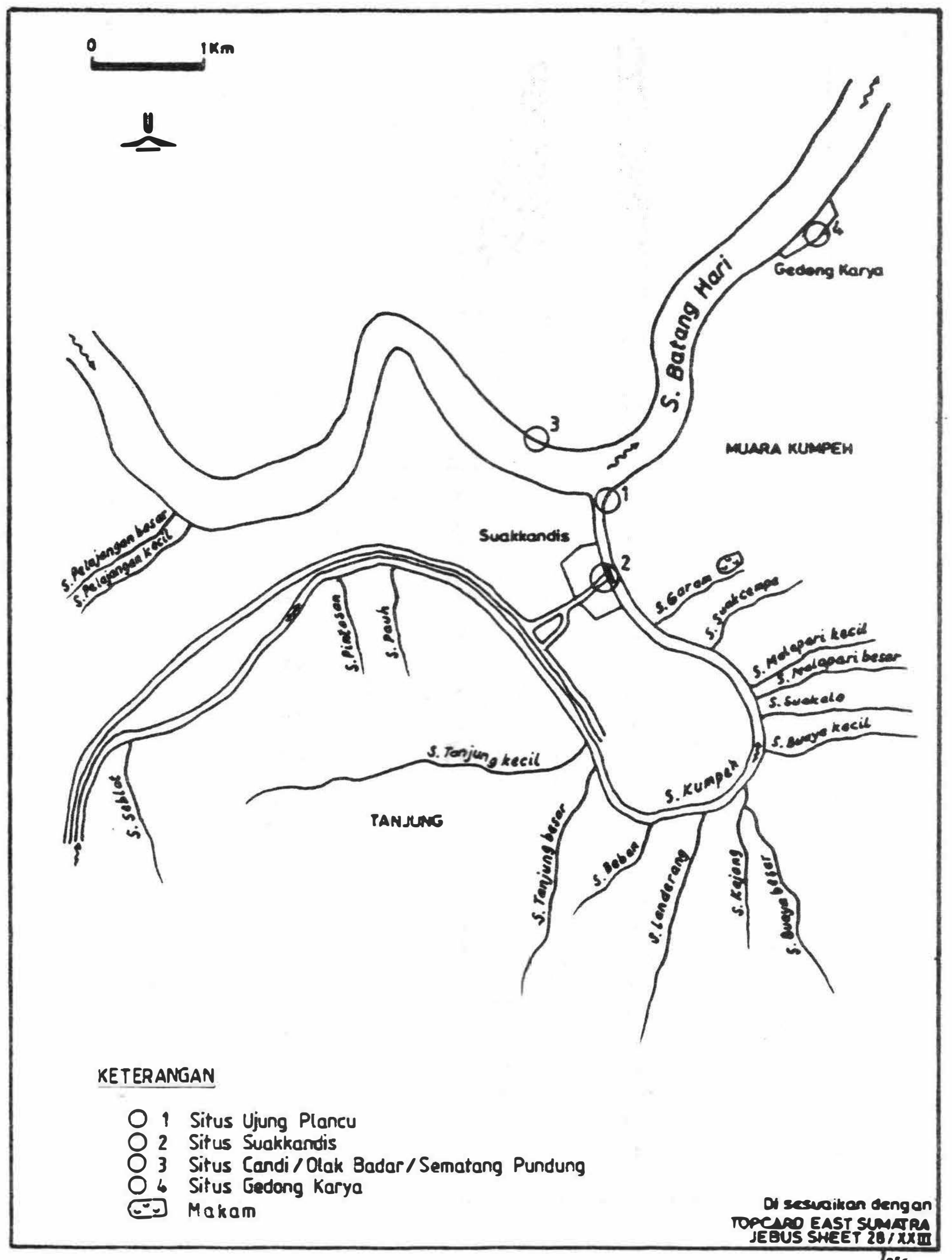

JEBUS SHEET $20 / \times \times 11$

Gambar 1. Peta keletakan situs Ujung Plancu, Jambi. 


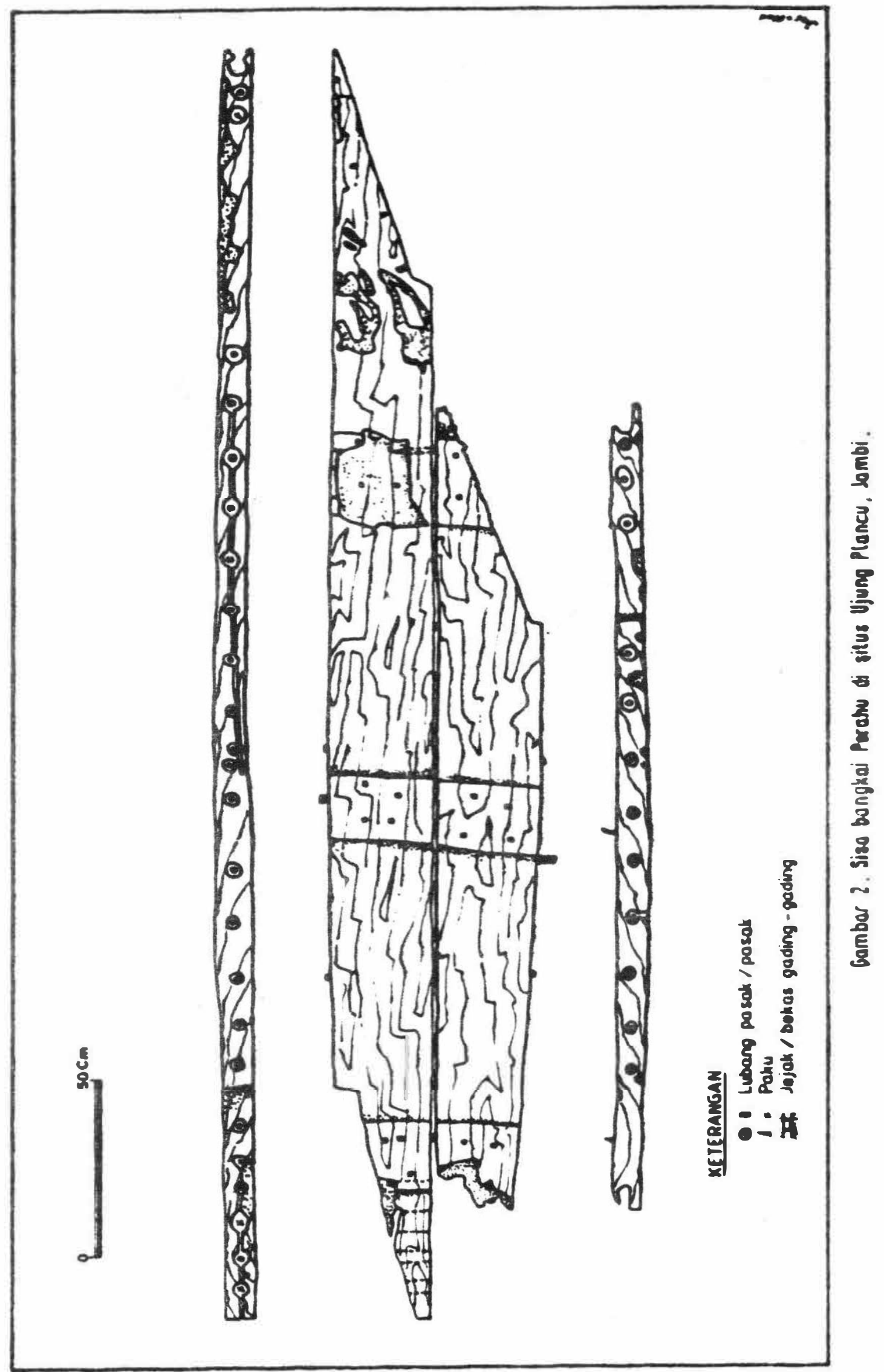

